\title{
PEAS (PISUM SATIVUM L.) WITH STRAIN SPECIFICITY FOR RHIZOBIUM LEGUMINOSARUM
}

\author{
B. E. KNEEN AND T. A. LARUE \\ Boyce Thompson Institute, Ithaca, New York 14853, USA
}

Received 9. ix. 83

\begin{abstract}
SUMMARY
Seven varieties of Pisum sativum from Afghanistan, Iran, Tibet and Turkey were tested for nodulation by 25 diverse strains of Rhizobium leguminosarum. The pea varieties were resistant to nodulation by 13 rhizobial strains from temperate regions, and formed few or no nodules. The varieties nodulated with 4 of 12 rhizobial strains from Middle Eastern soils. The plant-rhizobia specificity was identical to Pisum sativum var. "Afghanistan".

Crosses were made among five nodulation resistant varieties and "Afghanistan". Genetic analysis indicates that the strain specific nodulation resistance in each of the five pea varieties is allelic with the sym-2 gene in "Afghanistan".

Surveys of worldwide pea collections have failed to discover varieties which are never nodulated by any rhizobial strain. There appears, however, to be a class of nodulation resistant peas from the Middle East which have the same restricted strain specificity.
\end{abstract}

\section{INTRODUCTION}

The wild pea Pisum sativum var. "Afghanistan" is resistant to nodulation by strains of Rhizobium leguminosarum from temperate soils. Generally no or only a few nodules are formed (Lie et al., 1976). Lie reported that a single gene was involved, but genetic analysis was not published. Holl (1975) reported that $F_{2}$ plants from crosses of "Afghanistan" with nodulating cultivar "Trapper" segregated $3: 1$ nodulated to non-nodulated. A recessive allele (sym-2) was associated with non-nodulation.

Nodulation on "Afghanistan" is rhizobial strain specific. Lie (1978a) found a $R$. leguminosarum strain, TOM (from Tomek, Turkey), which formed effective nodules with "Afghanistan" under aseptic conditions. Lie isolated other infective strains from soil samples from Middle East locations. Lie et al., $(1978 b)$ found that European strains of $R$. leguminosarum blocked the formation of nodules on "Afghanistan" by strain TOM, though the European strains themselves were not infective on "Afghanistan". The gene(s) responsible for the ability of strain TOM to nodulate "Afghanistan" peas are carried on a plasmid, pRL5JI, as shown by conjugation experiments (Brewin et al., 1980).

Other nodulation resistant peas were discovered in a survey of 2000 Pisum cultivars from the USDA Plant Introduction collection (Holl, 1975; Holl and LaRue, 1976). They were obtained by screening with a commercial inoculant mixture, and not tested further for strain specificity. More recently, a smaller screen of 375 pea varieties was conducted at the John Innes Institute (Young et al., 1982a, 1982b). Twenty-six lines, nearly all from Afghanistan, were resistant to a strain of $R$. leguminosarum from England, 
but were nodulated by TOM. Further tests indicated those 26 varieties were nodulated by another strain containing the TOM plasmid, pRL5JI. The pea lines were phenotypically similar to each other, and to "Afghanistan", being characterised by small flowers and pods, brown marbled seeds, and resistance to powdery mildew. No crosses were made to determine if there was a common genetic basis for the strain specificity.

Six other putative non-nodulating pea varieties identified by Holl (1975) were tested for strain-specific nodulation using 25 diverse strains of $R$. leguminosarum. $F_{1}$ and $F_{2}$ progeny of crosses made among the nodulation resistant pea varieties were scored for nodulation using a single strain of $R$. leguminosarum. The pattern of strain specificity and the genetic analysis reported here indicate that nodulation in these peas is under control of the same gene (sym-2) as in "Afghanistan".

\section{MATERIALS AND METHODS}

\section{(i) Pea varieties}

Seven nodulation-resistant varieties of Pisum sativum from the Middle East, and two nodulating, North American cultivars (table 1) were tested for nodulation.

TABLE 1

Origin and characteristics of Pisum sativum lines

\begin{tabular}{|c|c|c|}
\hline Variety & Characteristics & Source \\
\hline "Sparkle" & $\begin{array}{l}\text { garden pea } \\
\text { dwarf, white flowered; green, wrinkled seeds }\end{array}$ & 1 \\
\hline “"Trapper" & $\begin{array}{l}\text { field pea } \\
\text { tall, white flowered; seeds smooth, yellow }\end{array}$ & 1 \\
\hline "Afghanistan" & $\begin{array}{l}\text { nodulation-resistant (JI 1357, SVP 57425) } \\
\text { tall, anthocyanin; smooth, yellow, mottled seeds }\end{array}$ & 2 \\
\hline PI 173055 & $\begin{array}{l}\text { ecotype elatius from Dara, Turkey, "Hatun Bakleri" } \\
\text { tall, anthocyanin, branching, serrated leaves, smooth, yel- } \\
\text { low, dark, gritty, hard coated seeds }\end{array}$ & 3 \\
\hline PRL 71HS2 & $\begin{array}{l}\text { non-nod selection from PI 140165, from Afghanistan, } \\
\text { "Moshung" (JI 95, WS 1418)* } \\
\text { tall, anthocyanin; smooth, yellow, mottled, speckled seeds }\end{array}$ & 4 \\
\hline PRL 71HS5 & $\begin{array}{l}\text { non-nod selection from PI 175228, from Takhlakot, Tibet } \\
\text { "Shratma" } \\
\text { tall, anthocyanin; smooth, yellow, mottled seeds }\end{array}$ & 4 \\
\hline PRL 71HS7 & $\begin{array}{l}\text { non-nod selection from PI 198735, from Ghazni, south of } \\
\text { Kabul (JI 97, WS 1420)* } \\
\text { tall, anthocyanin; smooth, yellow, mottled, speckled seeds }\end{array}$ & 4 \\
\hline PRL 72HS1 & $\begin{array}{l}\text { non-nod selection from PI 210631, "Early Wales" } \\
\text { tall, anthocyanin; smooth, yellow, mottled seeds }\end{array}$ & 4 \\
\hline PRL 72HS2 & $\begin{array}{l}\text { ecotype elatius, non-nod selection from PI } 227258 \text {, from } \\
\text { Esfahan, Iran } \\
\text { tall, anthocyanin; smooth, yellow, mottled seeds }\end{array}$ & 4 \\
\hline
\end{tabular}

Sources: 1 . Commercial cultivars 2. T. Lie, Wageningen, The Netherlands 3. USDA Plant Introduction Station, Geneva, New York 4. Prairie Regional Lab, NRC, Saskatoon, Canada.

* References to numbers used in Pisum collections: PRL = Prairie Regional Lab, NRC, Saskatoon, Canada PI = USDA Plant Introduction Service JI = John Innes Institute, England WS = Weibullsholm, Sweden SVP = Stichting voor Plantenveredeling, Wageningen, Netherlands 
(ii) Rhizobium leguminosarum strains

The sources of the rhizobial strains and their countries of origin are shown in table 2. Commercial pea inoculant was from the Nitragin Co., Milwaukee, Wisc.

TABLE 2

Strains of Rhizobium leguminosarum tested for infectivity

\begin{tabular}{llc}
\hline Strain & Country of origin & Source* \\
\hline ATCC 10004 & U.S.A. & 1 \\
$128 C 53-s m r$ & U.S.A. & 2 \\
300 & England & 3 \\
NA501-1, NA502-1, NA503, NA504-2, NA505, & Australia \\
NA525, NA533, CC1019, SU391, TA101 & & \\
BB54b, L28a, PS3a & Syria & \\
510P, 511P & Israel & 5 \\
TOM & Turkey & 6 \\
[Bez3, F72, F77, F81, FPecl, FPec4, FPec16] & & 7 \\
\hline
\end{tabular}

* Source 1, American Type Culture Collection, Beltsville, MD, USA; 2, J. Burton, Nitragin Co., Milwaukee, WI, USA; 3, J. Beringer, John Innes Institute, Norwich, UK; 4, Prairie Regional Lab, NRC, Saskatoon, Canada; 5, R. Islam, ICARDA, Aleppo, Syria; 6, Volcani Institute, Israel; 7, T. Lie, Wageningen, The Netherland; 8, N. Ulgen, Soil and Fertilizer Research Institute, Yenimahalle, Ankara, Turkey.

The $R$. leguminosarum strains were derived from single colonies on yeast-mannitol Congo red agar (YMA-CR) plates (Vincent, 1970). All, except CC1019, PS3a, Bez3 and F72 which form white nodules, form pink nodules on cultivars "Sparkle" $(>50)$ and "Trapper" $(>90)$. Cultures were maintained on yeast-mannitol agar slants, and inoculum for infectivity tests was grown at $30^{\circ}$ for 2 days in yeast-mannitol broth (YMB).

\section{(iii) Infectivity tests}

Surface sterilised seeds were planted in autoclaved $180 \mathrm{ml}$ Dispo bottles (American Scientific Products, Rochester, NY) containing vermiculite and $100 \mathrm{ml}$ nitrogen-free nutrient solution $\left(\mathrm{KH}_{2} \mathrm{PO}_{4}, 0.27 \mathrm{~g} ; \mathrm{K}_{2} \mathrm{SO}_{4}, 0.35 \mathrm{~g}\right.$; $\mathrm{MgSO}_{4} .7 \mathrm{H}_{2} \mathrm{O}, 0.25 \mathrm{~g} ; \mathrm{CaSO}_{4} .2 \mathrm{H}_{2} \mathrm{O}, 0.37 \mathrm{~g} ; \mathrm{FeC}_{6} \mathrm{H}_{5} \mathrm{O}_{7}, 0.03 \mathrm{~g} ; 1 \mathrm{ml}$ of micronutrient stock (containing $\mathrm{H}_{3} \mathrm{BO}_{3}, 4.0 \mathrm{~g} ; \mathrm{MnCl}_{2} .4 \mathrm{H}_{2} \mathrm{O}, 1.0 \mathrm{~g}$; $\mathrm{ZnSO}_{4} .7 \mathrm{H}_{2} \mathrm{O}, 0.575 \mathrm{~g} ; \mathrm{CuSO}_{4} .5 \mathrm{H}_{2} \mathrm{O}, 0.125 \mathrm{~g} ; \mathrm{Na}_{2} \mathrm{MoO}_{4} .2 \mathrm{H}_{2} \mathrm{O}, 0.103 \mathrm{~g}$ $\left.11 \mathrm{H}_{2} \mathrm{O}\right) ; 11 \mathrm{H}_{2} \mathrm{O} ; p \mathrm{H} 6 \cdot 8$ ). Seedlings were inoculated 4 days after planting with $4 \mathrm{ml}$ of rhizobial culture $\left(10^{8}\right.$ cells $\left./ \mathrm{ml}\right)$, the surface covered with parafinised sand (Vincent, 1970), and seedlings grown in temperature controlled lightrooms. A combination of metal halide and high pressure sodium lamps provided $555 \mathrm{~m} \mathrm{E} / \mathrm{m}^{2} \mathrm{~s}$. The light/dark regime was $16 \mathrm{~h} / 8 \mathrm{~h}$ and $21 \mathrm{C} / 18 \mathrm{C}$. Nodules were counted 17 days after inoculation. Each treatment was replicated at least three times. Strains which nodulated any Middle Eastern pea line were retested on "Sparkle", "Afghanistan", 71HS2, 71HS5, 71HS7 and 72HS2. 


\section{(iv) Genetic analysis}

To test for allelism, "Afghanistan", 71HS2, and PI 173055 were reciprocally crossed in a diallel mating design, and each crossed to "Sparkle". Lines 71HS5, 71HS7 and 72HS2 were crossed with "Afghanistan". Progenies were scored for seed traits, then planted in $7 \mathrm{~cm}$ pots of sand/vermiculite $1: 2$, and fertilised with nitrogen-free nutrient solution in the lightrooms. Seedlings were inoculated with $R$. leguminosarum $128 \mathrm{C} 33-\mathrm{smr}$ 4-7 days after planting, and scored for shoot characteristics and nodulation 17-23 days after inoculation. The $F_{1}$ seedlings were then transferred to complete substrate (Cornell $\mathrm{mix}$ ) and grown to maturity in the light rooms. Their progenies were scored for seed traits, and the $F_{2}$ seedlings tested for nodulation.

\section{RESULTS}

\section{(i) Infectivity tests}

The nodulation resistant varieties formed none or very few nodules with the rhizobial strains from temperate regions (table 3 ). The occasional nodules yielded rhizobial isolates which nodulated "Sparkle", but did not again form nodules on the resistant varieties. In addition to TOM, three rhizobial strains from the Middle East formed pink nodules on all the nodulation-resistant varieties. Two of the infective strains were from Israel, and one from Syria. It is noteworthy that the seven pea lines showed nearly identical patterns of strain specificity (table 3 ) with the 25 rhizobial strains tested.

\section{(ii) Genetic analysis}

$R$. leguminosarum $128 \mathrm{C} 53$-smr usually formed at least 30 pink nodules on "Sparkle" controls, while few $(<5)$, if any, nodules developed on "Afghanistan", 71HS2, 71HS5, 71HS7, and 72HS2. PI 173055 occasionally had as many as 25 nodules. All $F_{1}$ and $F_{2}$ progenies of crosses among nodulation-resistant lines fell within the "non-nod" parental class (table 4). The lack of nodulating recombinants in the progeny indicates the same gene controls nodulation resistance in the five lines crossed to "Afghanistan".

In comparison, crosses between nodulation-resistant lines and "Sparkle" produced nodulating $F_{1}$ progeny. $F_{2}$ segregation ratios for nodulation were not clear, since progeny included seedlings with intermediate numbers of nodules, as well as nodulation resistant and well nodulated parental types. Testing for nodulation with two other strains of $R$. leguminosarum, PRE and 300, has not resulted in clear segregation ratios in "Sparkle" $\times$ "Afghanistan" $F_{2}$ progeny.

\section{Discussion}

The lack of nodulating recombinants in progeny of crosses among nodulation-resistant lines and the nearly identical rhizobial strain specificity shown by them is convincing evidence that the strain-specific nodulation resistance genes in these seven lines are allelic. 
TABLE 3

Infection of Pisum lines by Rhizobium leguminosarum

\begin{tabular}{|c|c|c|c|c|c|c|c|}
\hline \multirow{2}{*}{$\begin{array}{l}R . \text { leguminosarum } \\
\text { Strain }\end{array}$} & \multicolumn{4}{|c|}{ Pea varieties } & \multirow[b]{2}{*}{$71 \mathrm{HS} 7$} & \multirow[b]{2}{*}{ 72HS1 } & \multirow[b]{2}{*}{$72 \mathrm{HS} 2$} \\
\hline & Afghanistan & 71HS2 & PI173055 & 71HS5 & & & \\
\hline \multicolumn{8}{|l|}{ "Temperate" strains } \\
\hline $128 \mathrm{C} 53-\mathrm{smr}$ & - & - & - & - & - & - & - \\
\hline ATCC 1004 & - & - & - & - & - & - & - \\
\hline 300 & - & - & - & - & - & ND & - \\
\hline NA501-1 & - & - & - & - & - & ND & - \\
\hline NA502-1 & - & - & - & - & - & ND & - \\
\hline NA503 & - & - & - & - & - & ND & - \\
\hline NA504-4 & - & - & - & - & - & ND & - \\
\hline NA505 & - & - & - & - & - & ND & - \\
\hline NA525 & - & - & - & - & - & ND & - \\
\hline NA533 & - & - & - & - & - & ND & - \\
\hline CC1019 & - & - & - & - & + & ND & + \\
\hline SU391 & - & - & - & - & - & ND & - \\
\hline TA101 & $(+)$ & - & - & - & - & ND & - \\
\hline "Nitragin" & - & - & - & - & - & ND & - \\
\hline \multicolumn{8}{|c|}{ Middle Eastern Strains } \\
\hline PS3a & - & - & ND & - & - & - & - \\
\hline Bez3 & - & - & - & - & - & ND & - \\
\hline F72 & - & - & - & - & - & ND & - \\
\hline F81 & - & - & - & - & - & ND & - \\
\hline FPec 1 & - & - & - & - & - & ND & - \\
\hline FPec 4 & - & - & - & - & - & ND & - \\
\hline FPec 16 & - & - & - & - & - & ND & - \\
\hline L28a & - & $(+)$ & - & - & - & ND & - \\
\hline $510 \mathrm{P}$ & + & + & + & $(+)$ & + & + & + \\
\hline $511 \mathrm{P}$ & + & $(+)$ & + & $(+)$ & + & + & + \\
\hline BB54b & + & + & + & + & + & + & + \\
\hline TOM & + & + & + & + & + & + & + \\
\hline
\end{tabular}

- = nodulation resistant, $<5$ nodules.

$(+)=$ occasional nodulation, $>5$ nodules on some plants.

$+=$ normal nodulation, $>5$ nodules on at least $5-6$ replicates

number of nodules per plant $=5-20$ on $71 \mathrm{HS} 5,173055 ; 5-25$ on Afghanistan; $5-35$ on $71 \mathrm{HS} 2,72 \mathrm{HS} 1 ; 10-45$ on $71 \mathrm{HS} 7,72 \mathrm{HS} 2,>50$ on "Sparkle"; $>90$ on "Trapper"

$\mathrm{ND}=$ not determined

Analysis of "Afghanistan" $X$ "Trapper" $F_{2}$ progeny showed that nodulation-resistance was associated with a single recessive gene designated sym-2 (Holl, 1975). Lie reported that segregation for nodulation of $F_{2}$ progeny from "Afghanistan" $\times$ "Rondo" crosses was strain dependent. When $\boldsymbol{R}$. leguminosarum PRE was used as the test strain nodulation resistance was due to a single dominant gene (Lie et al., 1976). We have not been able to confirm that resistance to nodulation is controlled by a single gene in "Afghanistan" $x$ "Sparkle" progeny. Non-parental plant types with intermediate numbers of nodules are found in $F_{2}$ progeny scored with $R$. leguminosarum strains $128 \mathrm{C} 53,300$ or PRE.

Nodule number may be modified by genetic background. Even with the rhizobial strain TOM, nodule number on "Afghanistan" is lower than on "Sparkle". We are, therefore, backcrossing "Sparkle" $x$ "Afghanistan" $F_{2}$ 
TABLE 4

Segregations for nodulation in the $F_{1}$ and $F_{2}$ generations in crosses among nodulation resistant pea lines

\begin{tabular}{|c|c|c|c|c|c|}
\hline \multirow[b]{2}{*}{ Cross } & \multicolumn{2}{|r|}{$F_{1}$} & \multicolumn{3}{|c|}{$\mathrm{F}_{2}$} \\
\hline & $\begin{array}{l}\text { No. of } \\
\text { crosses }\end{array}$ & $\begin{array}{c}\text { Ratio } \\
\text { (nodulation } \\
\text { resistant: } \\
\text { normal) }\end{array}$ & $\begin{array}{l}\text { No. of } \\
\text { crosses }\end{array}$ & $\begin{array}{c}\text { No. of } \\
F_{1} \text { plants }\end{array}$ & $\begin{array}{c}\text { Ratio } \\
\text { (nodulation } \\
\text { resistant: } \\
\text { normal) }\end{array}$ \\
\hline $\begin{array}{l}\text { 71HS2 } \times \text { Afghanistan } \\
\text { Afghanistan } \times 71 \text { HS2 }\end{array}$ & $\begin{array}{r}6 \\
18\end{array}$ & $\begin{array}{l}19: 0 \\
43: 0\end{array}$ & $\begin{array}{l}2 \\
3\end{array}$ & $\begin{array}{l}2 \\
7\end{array}$ & $\begin{array}{r}95: 0 \\
194: 0\end{array}$ \\
\hline $\begin{array}{l}173055 \times \text { Afghanistan } \\
\text { Afghanistan } \times 173055\end{array}$ & $\begin{array}{l}4 \\
2\end{array}$ & $\begin{array}{r}13: 0 \\
2: 0\end{array}$ & $\begin{array}{l}2 \\
1\end{array}$ & $\begin{array}{l}2 \\
2\end{array}$ & $\begin{array}{r}36: 0 \\
132: 0\end{array}$ \\
\hline $\begin{array}{l}71 \mathrm{HS} 2 \times 173055 \\
173055 \times 71 \text { HS } 2\end{array}$ & $\begin{array}{l}6 \\
1\end{array}$ & $\begin{array}{r}13: 0 \\
5: 0\end{array}$ & $\begin{array}{l}4 \\
1\end{array}$ & $\begin{array}{l}4 \\
2\end{array}$ & $\begin{array}{l}83: 0 \\
33: 0\end{array}$ \\
\hline $71 \mathrm{HS} 5 \times$ Afghanistan & 1 & $3: 0$ & 1 & 1 & $63: 0$ \\
\hline 71HS7 $\times$ Afghanistan & 2 & 3:0 & 2 & 3 & $75: 0$ \\
\hline $72 \mathrm{HS} 2 \times$ Afghanistan & 1 & $4: 0$ & 1 & 4 & $84: 0$ \\
\hline
\end{tabular}

non-nodulating selections to "Sparkle", in an attempt to separate the effects of the sym-2 gene from other genetic modifiers of nodule number.

Not all rhizobial strains from Middle East soils formed nodules on the nodulation-resistant pea lines. The four infective strains are from Turkey, Syria and Israel, and they differ in some cultural characteristics (Kneen and LaRue, 1983). The infectivity of TOM is associated with an atypical plasmid (Brewin et al., 1980). It would be interesting to learn if a similar plasmid is present in the three additional strains we found to infect "Afghanistan".

After examining the putative non-nodulating peas reported by Holl (1975), we find that all nodulate with appropriate strains of rhizobia. In agreement with Young et al., $(1982 b)$, we conclude that there is a class of peas, exemplified by "Afghanistan", with a restricted strain specificity. Additional pea genotypes defective in the symbiosis are desirable in order to study the host plant contribution to nitrogen fixation. These may have to be obtained by artificial mutagenesis.

Little is known about the plant or rhizobial genes which control the specificity of nodule formation. The "Afghanistan"-TOM (sym-2, sym-2pRL5J1) association is one in which something is known of the genetics of both symbionts.

Devine and Weber (1977) proposed for agriculture the development of legume cultivars which exclude indigenous rhizobial strains while selectively forming nodules with specific introduced strains. A model for this conditional specificity system may be a strain specific ( $s y m-2$, sym-2) pea which would exclude indigenous rhizobia in temperate soils, but admit introduced competitive strains bearing the pRL5J1 plasmid. Clearly, the "Afghanistan"-like peas deserve further study.

Acknowledgements. We are grateful for the generous help and advice of Dr G. A. Marx. The research was supported by U.S. Department of Agriculture grant CRGO 79-00103. 


\section{REFERENCES}

BREWIN, N. J., BERINGER, J. E. AND JOHNSTON, A. W. B 1980. Plasmid-mediated transfer of host range specificity between two strains of Rhizobium leguminosarum. J. Gen. Microbiol., 120, 413-420.

DEVINE, T. E. AND WEBER, D. F. 1977. Genetic specificity of nodulation. Euphytica, 26, 527-535.

HOLL, F. B. 1975. Host plant control of the inheritance of dinitrogen fixation in the PisumRhizobium symbiosis. Euphytica, 24, 767-770.

HOLL, F. B. AND LARUE, T. A. 1976. Host genetics and nitrogen fixation. In Hill, L. D. (ed.) Proc. World Soybean Conference, Urbana, Illinois, The Interstate Printers and Publishers, Inc., Danville, pp. 156-163.

KNEEN, B. E. AND LARUE, T. A. 1983. Congo red absorption by Rhizobium leguminosarum. Appl. Envir. Microbiol., 45, 340-342.

LIE, T. A., HILLE, D. LAMBERS, RIS AND HOUWERS, A. 1976. Symbiotic specialization in pea plants: some environmental effects on nodulation and nitrogen fixation. In Numan P. S. (ed.) Nitrogen Fixation in Plants Cambridge University Press, Cambridge, pp. 319-333.

LIE, T. A. 1978a. Symbiotic specialization in pea plants: the requirement of specific $R$ hizobium strains for pea from Afghanistan. Ann. Appl. Biol. 88, 462-465.

LIE, T. A., WINARNO, R. AND TIMMERMANS, P. C. J. M. 1978 b. Suppression of nodulation by a non-nodulating Rhizobium strain. In Loutil, M. W. and Miles, J. A. R. (eds.) Microbial Ecology Springer-Verlag, Berlin, pp. 398-401.

VINCENT, J. M. 1970. A Manual for the Practical Study of the Root-Nodule Bacteria, I.B.P. Handbook No. 15, Blackwell Scientific Publications, Oxford.

YOUNG, J. P. W., JOHNSTON, A. W. B. AND BREWIN, N. J. 1982a. A search for peas (Pisum sativum L.) showing strain specificity for symbiotic Rhizobium leguminosarum. Heredity, 48, 197-201.

YOUNG, J. P. W. AND MATTHEWS, P. 1982b. A distinct class of peas (Pisum sativum L.) from Afghanistan that show strain specificity for symbiotic Rhizobium. Heredity, 48, 203-210. 